\title{
Academic Outcomes of High School Students in Northern Ghana: The Mediator Role of Locus of Control
}

\author{
Ziblim Abukari \\ Associate Professor, Department of Social Work, \\ Westfield State University, 577 Western Ave, \\ Westfield, MA o1086, United States \\ Corresponding Author \\ Mohammed Adams Mashoud \\ Lecturer, Department of Communication, Innovation and Technology, \\ Faculty of Agribusiness and Communication Sciences, University for Development Studies, \\ P. O. Box 1882, Nyankpala Campus, Tamale, Ghana \\ Alhassan Baba Andani \\ Lecturer, Tamale Technical University, \\ P. O. Box 1, Tamale, Ghana
}

Doi: 10.36941/jesr-2020-0o11

\section{Abstract}

The purpose of this quantitative study was to investigate the relationship between academic outcomes and locus control beliefs among high school students in the Northern Region of Ghana. Using survey methods and multivariate analyses, the results found relatively higher scores in external locus of control beliefs than internal locus of control beliefs among the study participants. External locus of control was inversely related to test scores, and no relationship was found between internal locus of control beliefs and test scores. The results also found significant differences in locus of control beliefs between rural and urban high school students, with urban students reporting higher internal locus of control beliefs than their rural counterparts. Implications for educational policy and practice are discussed.

Keywords: Locus of Control, academic outcomes, test scores, Ghana, gender differences, locality

\section{Introduction and Background}

Education has long been recognized by many researchers as a significant predictor of a better future, and scholars from varied backgrounds consider education as a consistent childhood predictor in many adult developmental outcomes (Fobih, 1897; Garmezy, Masten, \& Tellegen, 1984; Ndom, Elegbeleye, \& Sunmonu, 2008; Schoon, 2006; Werner \& Smith, 1992). Evidence suggest that without proper education and training, individuals will fail to develop the necessary skills to work in a modern economy or avail themselves of the opportunities it offers (Garmezy et al., 1984; Schoon, 2006). Recent research into Ghanaian youth's academic achievement has primarily focused on risks 
factors or barriers to educational success (e.g., Abukari, 2018; Abukari \& Laser, 2013; Amponsah, Ametefe, \& Mensah, 2012), school and teacher characteristics (e.g., Abdallah, Fuseini, Abudu, \& Nuhu, 2014; Chowa, Masa, Ramos, \& Ansong, 2015), and gender influence (Author, 2013; Dunne, Leach, Chilisa, Maundeni, Tabulawa, \& Kutor, 2005; Fentiman, Hall, \& Bundy, 2001; Hunter, 2001; White, 2004). While these factors have increased our understanding of the barriers and opportunities to educational achievement in Ghana, they do not encompass all the determinants of academic achievement.

Academic achievement in Ghana has been confounded by spatial and structural factors dating back to the colonial era when the British colonial occupiers deliberately excluded the then Northern Territories, now Northern Ghana, from all forms of formal education (Bening, 1990; McWilliam \& Kwamena-Poh, 1975; Saaka, 2001). As a result, formal education started later in northern Ghana and regional disparities in academic outcomes have remained one of the most glaring of these differences, and continue to be a concern for governments, educational administrators as well as researchers. The region has also consistently underperformed in all educational indicators with rural areas lagging farther behind in educational infrastructure, quality teachers, and enrollment (Ghana Statistical Survey, 2014).

This is particularly concerning because low academic achievement is related to low socioeconomic status, and many negative behavior outcomes such as violence, substance abuse, and unemployment (Abukari, 2007; Choi, 2007). However, socioeconomic status and environmental factors are not the only determinants of academic achievement. Locus of control has been identified as a psychological factor associated with behavior reinforcement including students' attitude toward participation and achievement in school (Nunn, Montgomery \& Nunn, 1986; Skaalvik \& Skaalvik, 2004). Academic achievement is often measured in reference to GPA and test scores as well as the number of years of school completed and diplomas awarded (Choi, 2007; Rumberger, 2001). Academic achievement in this study is measured using continuous assessment scores in math, science, and English Language.

The purpose of this study was to examine the relationship between academic outcomes and locus of control among high school students in the Northern Region of Ghana. Extant research has established a relationship between low parental education or lack thereof and low academic outcome of their children (Chingtham \& Guite, 2017; Tansel, 1997). As Chingtham and Guite (2017) rightly observed, a parent's positive attitude toward their children's education is an important predictor of school attendance and their academic achievement. But they added that parental attitude toward their children's education is predicated on their socioeconomic status and insinuated that lowincome parents tend to have more negative attitudes toward the education of their children. It is therefore no surprise that both enrollment and gender gaps are more prevalent in rural Northern Region as a result of high illiteracy rate and high incidence of poverty (Cooke, Hague, \& McKay,2016). Cooke and colleagues observe that while Ghana has experienced a robust average economic growth of over $7 \%$ per year and significant decline in poverty incidents, the Northern Region has only experienced a marginal decline and is home to the largest number of poor people in the country.

\section{Review of Literature}

\subsection{Locus of Control}

Some researchers believe that it is possible to predict the future performance of people by examining their internal and external beliefs with regards to how much control they have over life events (Finch, Spirito, Kendall, \& Mikulka, 1981; Nowicki \& Strickland, 1973). Rotter (1966) and Nowicki and Strickland (1973) describe these beliefs over the control of their own destiny as locus of control. A more recent study by Das and Pattanaik (2013) describe locus of control as a personality theory that explains individual beliefs about the degree to which they have control over events that affect their lives. Rotter (1966) grounded his theory of locus of control on the concept of reinforcement and its 
role in acquisition of knowledge, skills, and performance. According to Rotter (1966), writing in reference to academic achievement in the American society,

when a reinforcement is perceived by the subject as following some action of his own but not being entirely contingent upon his action, then, in our culture, it is typically perceived as the result of luck, chance, fate, as under the control of powerful others, or as unpredictable because of the great complexity of the forces surrounding him. When the event is interpreted in this way by an individual, we have labelled this a belief in external control. If the person perceives that the event is contingent upon his own behavior or his own relatively permanent characteristics, we have termed this a belief in internal control (p. 1), (emphasis original).

Locus of control is derived from social learning theory of reinforcement and personality theory. According to Rotter (1966), locus of control is predicated on a belief that when behavior is rewarded, expectancy is created, and the individual is inclined to continue that behavior. Rotter defined locus of control as the extent to which people believe in the power they have over events in their lives. Rotter (1966) suggested that individuals have different reactions based on where they believe the reward is coming from such as their own effort or being controlled by powerful individuals or forces. In Rotter's view, individuals who perceive reinforcement or reward as emanating from their own actions demonstrate internal locus of control beliefs. On the other hand, Rotter argues that individuals with external locus of control orientation believe that rewards occur randomly or by chance and blame outside forces for their behavior for which they have no control over. In this sense, individuals with external locus of control beliefs do not see rewards as a product of their own behavior; and lack the motivation to repeat or continue the behavior.

While Rotter (1966) initially conceptualized locus of control as internal versus external, Levenson $(1974,1981)$ extended the theory of locus of control with an argument that the concept involves more than the binary dimension conceptualized by earlier writers. In particular, Levenson (1974) claimed that early developers of the theory failed to explicitly explain the concept of external control and theorized that external locus of control emanates from two sources: powerful others and chance (or fate, bad luck) (Levenson, 1974). Based on this conceptualization, Levenson (1974) extended the binary method of measurement to a three-part scale: Internal, Powerful Others, and Chance (IPC). Levenson explained that the first category implies that other humans - that is, people in powerful positions and higher social rungs - are in control, the second dimension characterizes a belief in the random nature of the world, and belief in chance was particularly studied as a separate variable from powerful others. Despite the multidimensionality of Levenson's scale, some researchers such as Shechuk, Foelker, and Blandchard-Fields (1992) argue that the IPC has failed to provide sufficient construct validity when applied to different disciplines. The authors also criticized the IPC scale for not being suitable for all ages since it was only tested on undergraduate students. In order to avoid the criticisms of the earlier locus of control scales, Nowicki and his colleagues (Nowicki, 1976; Nowicki \& Duke, 1974; Nowicki \& Strickland, 1973) developed different scales that were age-specific. For example, the Nowicki and Strickland's (1973) locus of control scale for children and Nowicki and Duke's (1974) locus of control for adults have been used extensively by researchers. Specifically, Nowicki and Strickland (1973) locus of control scale for children was developed out of Rotter's (1966) theory of locus of control. The 40-item scale consists of yes- or no questions based on different reinforcement scenarios. This instrument has demonstrated good construct validity in their studies of relationship among locus of control, academic achievement, and age (Nowicki \& Strickland, 1973).

Other researchers (e.g., Chandler \& Gugovics, 1977; Kendall, Finch, Little, Chirico \& Ollendick, 1978; Finch, Sipiroto, Kendall, \& Mikulka, 1981) have tested the multidimensionality of NowickiStrickland (1973) locus of control scale. For example, Finch et al. (1981) administered the Adult Nowicki-Strickland Locus of Control Scale (ANS-IE) to 120 undergraduate psychology students. A factor analysis yielded five major factors that accounted for $81 \%$ of the total variance, which they found to be similar to the children's version of the Nowicki-Strickland scale. The constructs were also similar to those found in previous studies. According to Finch and colleagues (1981), the first two 
factors, when combined produce the construct of helplessness, which is consistent with Kendall et al. (1978) in their study of preschool and primary school children using the children version of the Nowicki-Strickland scale, as well as Chandler and Dugovics (1977) notion of powerlessnesshelplessness. Fitch and colleagues (1981) explain that while helplessness connotes an inability to protect oneself, powerlessness is characterized by lack of social power.

Similarly, Fitch et al. (1981) classified the third factor as superstition and luck, noting that these beliefs are indicative of a belief in the notion of a "good day" and pure luck. This finding was similar to the superstition factor described by Kendall et al. (1978) as well as the luck factor in Nowicki (1976). Factors four and five which Finch et al. (1981) describe as futility and persecution "suggests passivity and a "why bother attitude" and a tendency to perceive every effort as meaningless as a result of unfair contingencies. These descriptions are similar to Kendall et al. (1978) description of personal control and blame in their study of the quantitative and qualitative differences in children's locus of control among emotionally disturbed and delinquent elementary school children.

\subsection{Locus of Control and Academic Achievement}

The relationship between locus of control and academic achievement has been widely studied. While there is no consensus on the degree to which academic achievement is associated with locus of control, many studies find a relationship between the two. In a meta-analysis conducted by Findley and Cooper (1983) to compare locus of control to academic achievement, they found a positive correlation between the two variables in $70 \%$ of the 275 hypotheses tested. According to the authors, students with internal locus of control beliefs had significant academic achievement scores than their counterparts with external locus of control beliefs, with only nine percent showing negative correlation.

Similarly, Shepherd, Owen, Fitch, and Marshall (2006) have reported that internal locus of control beliefs can be a predictor of academic performance. Several studies suggest that the relationship between internal locus of control and academic achievement is not unique to specific social or cultural context. Several studies in other countries have reported positive relationships between internal locus of control and academic achievement (e.g., Das \& Pattanaik, 2013; Dubey \& Nayyar, 2016; Choudhury \& Borooah, 2017) in India; Khir, Redzuan, Hamsan, and Shahrimin (2015) in Malaysia; Kishor (1983) in Fiji, and Ndom, Elegbeleye, and Sunmonu (2008) in Nigeria. For example, in a study of 402 secondary school students in Malaysia, Khir et al. (2015) reported significant differences among high achieving students and locus of control. This is consistent with Das and Pattanaik (2013) study as well as Dubey and Nayyar (2016) who found significant relationship between academic achievement and locus of control among students with internal locus of control beliefs compared to those with external locus of control.

Furthermore, Nongtu and Bhutia (2017) reported a significant relationship between internal locus of control and academic achievement among college students and secondary school students but no significant difference between genders. The authors also reported significant differences in locus of control beliefs between rural and urban students with urban students reporting higher internal locus of control than their rural counterparts. This is consistent with Khir et al. (2015) study of students in Malaysia who reported a negative correlation between academic achievement and external locus of control. Khir et al. also found that respondents with low socioeconomic status had lower achievement levels and reported higher external locus of control. This implies that respondents from poor families and rural areas that tend to be poor believe that their own actions have little influence on their behavior outcomes. Unlike earlier studies (e.g., Findley \& Cooper, 1983; Strickland \& Haley, 1980), some studies reported significant correlation between age and locus of control where younger respondents tend to externalize their actions and behavior with a sense of no control while older respondents reported higher internal locus of control (Khir, 2015). This is logical since younger people may lack insight to put their actions and behavior into proper perspective compared to older respondents who may draw lessons from life experiences. 
In addition, Strickland and Haley (1980) found significant gender differences in internalexternal locus of control. Using the Rotter I-E scale, Strickland and Haley (1980) asked the 400 participants in their study to choose either "super male" (that is, a person embodying extreme male gender characteristics) or "super female" (that is, a person embodying extreme female characteristics). Strickland and Haley (1980) reported that participants who chose "super male" regardless of gender, reported higher internal scores based on the I-E scale. Conversely, participants who chose "super female" irrespective of gender reported higher external scores. According to the authors, the response bias in the scale may be attributed more to gender role expectations in society than the actual positions of the participants. In a related study, Rinn and Boazman (2014) found that locus of control is related to academic dishonesty and inclination to cheat. The authors compared academic dishonesty tendencies between honor and non-honor students in relation to locus of control. While no relationship was found between locus of control and academic dishonesty, a small but significant correlation was found between an inclination to cheat and non-honors students.

In this study, we were interested in finding out whether locus of control particularly internal locus of control serves as a protective factor that promotes academic achievement. This study was designed to examine the following questions:

1. Given the cultural value of interdependence, will more students report higher scores on external controls than internal control?

2. Is there a relationship between internal locus of control beliefs and test scores in the English Language, math, and science?

3. Is there a relationship between external locus of control beliefs and test scores in the English Language, math, and science?

4. Are there gender differences in internal and external locus of control and academic outcomes in the three test scores in English language, math, and science?

5. Are there differences in locus of control beliefs between students in rural highs schools and those in urban high schools and test scores?

\section{Methodology}

The study was a cross-sectional descriptive survey design that examined the relationship between locus of control and academic achievement in high school students in the Northern Region of Ghana. Locality and gender were also examined with locus of control to see if any differences exist in relation to academic achievement.

\subsection{Participants}

The participants were 364 high school students from public government schools in the Northern Region of Ghana made up of 226 males and 134 females representing $63 \%$ and $37 \%$ respectively. The mean age was 18 years $(S D=1.69)$. The students came from four high schools, two in a metropolitan area and the other two from a rural district. In addition, half of the participants $(50 \%)$ were seniors while $44 \%$ were juniors, and the rest were unidentified. The sample population breakdown by school and gender is shown in Table 1.

\subsection{Procedures}

School headmasters or principals of the four high schools in two districts, selected purposively, approved the study and assisted in data collection. After permission from the children and parents were obtained by the headmasters, the classroom teachers in the four schools were given the research surveys that included an informed consent statement, a demographic form, and the NowickiStrickland (1973) Locus of Control Scale. Students were informed that their participation was voluntary and they could stop the survey even after they have agreed to participate and or refuse to 
answer any questions that made them uncomfortable. Students were not compensated, and those who agreed to participate completed the survey in class and returned them in an envelope to the teacher. Students self-reported their continuous assessment (CA) scores in English, math, and science on a form provided.

\subsection{Measures}

The Nowicki-Strickland Locus of Control Scale for Children (Nowicki \& Strickland, 1973), a paperand-pencil measure of 40 dichotomous questions, was given to students in the four high schools. As noted earlier, the Nowicki-Strickland (1973) scale was designed for children and has satisfactory psychometric properties. The scale has also been used extensively in past research as shown in the preceding review of literature. The 40-item binary scale is made up of positive and negative statements to measure internal-external locus of control. Negative or more external items are given 1 point per reply, and the higher the score, the more externally oriented the respondent. Conversely, more internally oriented responses are scored as zero. A sample question is "Most of the time, do you feel that getting good grades is good for you?" with response options of "Yes" or "No". The dependent measure consisted of students' self-reported assessment scores in English, math, and science. The assessments were scored out of 10o. Additional measures were location of school, (rural vs. urban), gender, and parental educational level.

\section{Results and Findings of the Study}

To examine the influence of locus of control beliefs on academic outcomes of high school students, the study collected data from four high schools in the Northern Region of Ghana. The students came from both rural and urban high schools with varying degrees of social amenities. Table 1 shows the demographic information of the research participants. As shown in Table 1, through listwise deletion in SPSS, there were 359 participants made up of 133 females and 226 males with a mean age ( $M=18$ years; $S D=1.59$ ). As shown in Table 1 , the number of male students was almost twice the number of female students, a reflection of gender inequality in the educational system in that region of the country. With regards to parental education for the total sample, $58 \%$ of mothers and $41 \%$ of fathers had no formal education at all. In addition, only six percent of mothers and nine percent of fathers reported to have college or university education. Parents with no formal education in the rural areas were higher reporting little or no university education in the rural schools, as shown in Table 1.

Table 1. Demographic Information of Participants

\begin{tabular}{|c|c|c|c|c|c|}
\hline Variable & $\begin{array}{c}\text { All } \\
\text { Students } \\
\mathrm{N}=359\end{array}$ & $\begin{array}{c}\text { Urban } \\
\text { School A } \\
(\mathrm{N}=88)\end{array}$ & $\begin{array}{c}\text { Urban } \\
\text { School B } \\
(\mathrm{N}=174)\end{array}$ & $\begin{array}{c}\text { Rural } \\
\text { School A } \\
(\mathrm{N}=44)\end{array}$ & $\begin{array}{c}\text { Rural } \\
\text { School B } \\
(\mathrm{N}=54)\end{array}$ \\
\hline Age (mean age in year) & $\begin{array}{l}18.34 \\
(1.59) \\
\end{array}$ & $\begin{array}{l}18.85 \\
(1.67) \\
\end{array}$ & $\begin{array}{l}17.70 \\
(1.24) \\
\end{array}$ & $\begin{array}{c}19.5 \\
(1.49) \\
\end{array}$ & $\begin{array}{l}18.63 \\
(1.65) \\
\end{array}$ \\
\hline \multicolumn{6}{|l|}{ Gender: } \\
\hline Female & 133 & 35 & 47 & 24 & 27 \\
\hline Male & 226 & 53 & 127 & 19 & 27 \\
\hline \multicolumn{6}{|l|}{ Parental Education } \\
\hline \multicolumn{6}{|c|}{ Mother's level of education (\%) } \\
\hline No education & 58.0 & 70.9 & 40.0 & 81.4 & 77.6 \\
\hline Some primary education & 14.9 & 11.6 & 19.4 & 14.0 & 6.1 \\
\hline Secondary education & 10.1 & 7.0 & 13.5 & 0.0 & 12.2 \\
\hline Islamic education & $4 \cdot 3$ & $3 \cdot 5$ & 7.1 & 0.0 & 0.0 \\
\hline University education & 6.0 & 2.3 & 8.8 & 4.7 & 4.1 \\
\hline Professional education & 6.6 & $4 \cdot 4$ & 11.2 & 0.0 & 0.0 \\
\hline
\end{tabular}




\begin{tabular}{lccccc}
\hline Father's level of education (\%) & & & & & \\
No education & 41.2 & 45.3 & 23.1 & 67.4 & 73.5 \\
Some primary education & 14.4 & 15.1 & 13.6 & 18.6 & 12.2 \\
Secondary education & 8.9 & 10.5 & 9.5 & 9.3 & 4.1 \\
Islamic education & 9.5 & 14.0 & 11.2 & 0.0 & 4.1 \\
University education & 9.2 & 0 & 17.2 & 0.0 & 6.1 \\
Professional education & 16.7 & 15.1 & 25.4 & 4.7 & 0.0 \\
\hline
\end{tabular}

The professional education category included teachers, nurses, and other forms of technical training. From Table 1, it shows that while $16.7 \%$ of all students reported a parent with professional education, the number of parents in rural schools with professional education was a paltry $4.7 \%$ in one school and none in another school, thereby revealing the disparity and a wide gap in educational participation between rural and urban areas in the region.

\subsection{Prevalence of External-Internal Locus of Control Beliefs}

In response to the first question, that given the interdependent and collectivistic culture in Ghana, will students would report higher scores in external locus of control and lower scores on internal locus of control? This question was informed by previous studies that suggest that societies with more communal and interdependent values like Ghana tend to utilize collective decision making with an inclination for deference to higher social power or ranks (e.g., Khir et al., 2015; Kishor, 1983; Nongtu \& Bhutia, 2017). A higher score in the locus of control scale suggests a more external locus of control beliefs (Nowicki-Strickland (1973). The total mean score for the entire sample was 15.94 $(S D=3.01)$. Using independent samples t-test, male students scored relatively lower $(M=14.82$; $S D=2.88)$ than female students $(M=15.13 ; S D=3.25)$ but the difference was not statistically significant. Similarly, students from urban schools had relatively lower external locus of control scores $(M=14.86$; $S D=2.98)$ compared to their rural counterparts $(M=15.19 ; S D=3.12)$. Again, the mean difference was not statistically significant.

With regards to internal locus of control beliefs, the overall sample mean was $(M=13.88$; $S D=2.51$ ). When broken down by gender and location, there was no significant difference by gender or locale.

4.2 Relationship between Internal-External Locus of Control and Test Scores in Math, English, and Science

In response to questions 2 and 3, we wanted to know if there is a relationship between internal locus of control beliefs and students' test scores in math, English, and science. We also tested a hypothesis that there will be no relationship between external locus of control beliefs and test scores in math, English, and science using Pearson correlations. To properly place this within the broader context of the study, we created dummy variables for school location (location), gender, and parental educational levels. The results show significant inverse relationships between location of school and mean test scores in English language and science as shown in Table 2. Even though the relationships were weak, they were statistically significant. As shown later in this section, students in urban high schools scored significantly higher than their rural counterparts in two of the three assessment scores. Similarly, gender is inversely related to the mean test scores in math and science. Concerning the correlations between internal locus of control and test scores, no significant relationship was found between internal locus of control and any of the three test scores in math, English, and science. However, as shown in Table 2, external locus of control was inversely correlated with math ( $r=-143$, $p<.001)$ and English $(r=-.145, p<.05)$, suggesting that students who scored higher on external locus of control performed poorly in these two subjects. 
Table 2. Summary of Intercorrelations among IE-Locus of Control and Scores in Math, English Language, and Math

\begin{tabular}{lccccccccc}
\hline Variable & 1 & 2 & 3 & 4 & 5 & 6 & 7 & 8 & 9 \\
\hline 1. Location & - & $.196^{* *}$ & $-.281^{* *}$ & $-.150^{* *}$ & -.098 & .048 & -.051 & $-.173^{* *}$ & $-.151^{*}$ \\
2. Gender & $.196^{* *}$ & - & .006 & -.006 & .057 & .050 & $-.218^{* *}$ & -.027 & $-.227^{* *}$ \\
3. Father's educational level & $-.281^{* *}$ & .006 & - & $.466^{* *}$ & .088 & $.135^{*}$ & -.026 & .004 & .020 \\
4. Mother's educational level & $-.150^{* *}$ & -.006 & $.466^{* *}$ & - & .086 & .094 & -.034 & .054 & .030 \\
5. Internal locus of control & -.098 & .057 & .088 & .101 & - & $.239^{* *}$ & -.043 & .011 & -.035 \\
6. External locus of control & .048 & .050 & $.135^{*}$ & .094 & $.239^{* *}$ & - & $-.143^{*}$ & $-.145^{*}$ & -.090 \\
7. Math & -.051 & $-.218^{* *}$ & -.026 & -.034 & -.043 & $-.143^{*}$ & - & $.743^{* *}$ & $.802^{* *}$ \\
8. English Language & $-.173^{* *}$ & -.027 & .004 & .054 & .011 & $-.145^{*}$ & $.743^{* *}$ & - & $.807^{* *}$ \\
9. Science & $-.151^{*}$ & $-.224^{* *}$ & .020 & 030 & -.035 & -.090 & $.802^{* *}$ & $.807^{* *}$ & - \\
\hline
\end{tabular}

${ }^{*} \mathrm{p}<.01 ;{ }^{* *} \mathrm{p}<.001$

\subsection{Differences in External-Internal Locus of Control Beliefs by Gender and Location}

Another objective of the study was to examine differences in external and internal locus of control beliefs between females and males and between students in urban versus students in rural areas. There is no consensus in existing literature about gender differences in external-internal locus of control beliefs and there are few existing studies that examine locality differences in external-internal locus of control beliefs. Using multivariate analysis of variance (MANOVA), Table 3 shows gender and locality differences in internal-external locus of control beliefs. As shown in Table 3, while females in the sample had a relatively higher score in internal locus of control $(M=14.08, S D=2.36)$ compared to males $(M=13.78, S D=2.64)$, the mean difference was not statistically significant. As reported earlier, female respondents scored higher on external locus of control $(M=15.94 ; S D=3.25)$ compared to males $(M=14.82 ; S D=2.88)$ but the difference was not statistically significant.

Table 3. Mean Differences in Locus of Control and Achievement Scores based on Gender and Location of School

\begin{tabular}{|c|c|c|c|c|c|c|c|c|c|c|c|c|}
\hline \multirow[t]{3}{*}{ Variable } & \multicolumn{4}{|c|}{ Gender } & \multicolumn{8}{|c|}{ Location } \\
\hline & \multicolumn{2}{|c|}{ Female $(\mathrm{N}=133)$} & \multicolumn{2}{|c|}{ Male } & \multicolumn{2}{|c|}{ Urban School A } & \multicolumn{2}{|c|}{ Urban School B } & \multicolumn{2}{|c|}{ Rural School A } & \multicolumn{2}{|c|}{ Rural School B } \\
\hline & $\mathrm{M}$ & SD & $\mathrm{M}$ & SD & $\mathrm{M}$ & SD & $\mathrm{M}$ & SD & $\mathrm{M}$ & SD & $\mathrm{M}$ & SD \\
\hline External LC & 11.08 & $3 \cdot 32$ & 10.81 & 2.80 & 10.61 & 3.21 & 11.02 & 2.79 & 11.20 & 3.01 & 10.90 & 3.43 \\
\hline Internal LC & 14.08 & 2.36 & 13.78 & 2.64 & 14.78 & 1.10 & 13.65 & 2.74 & $13 \cdot 57$ & 2.44 & 13.62 & 2.45 \\
\hline Math & 48.12 & 19.13 & $57 \cdot 41^{*}$ & 18.45 & $60.49^{*}$ & 14.69 & 51.92 & 18.39 & 65.42 & $15 \cdot 51$ & 41.45 & 24.11 \\
\hline English & 60.54 & 19.67 & 61.50 & 16.40 & $68.24^{*}$ & 11.17 & 59.74 & $13 \cdot 36$ & 68.54 & 12.07 & $44 \cdot 77$ & $24 \cdot 32$ \\
\hline Science & $55 \cdot 52$ & 19.29 & $64.80^{*}$ & 18.98 & $68.34^{*}$ & 13.47 & 60.50 & 19.26 & 68.50 & 13.28 & 46.10 & 26.13 \\
\hline
\end{tabular}

With regards to locality differences in locus of control beliefs, results from the multivariate analysis shows that students in the two rural schools scored relatively higher on external locus of control as shown in Table 3 but these differences were not statistically significant. Also, as shown in Table 3, while the mean external locus of control score in urban school A was 10.61, the mean score was 11.20 in rural school A. Similarly, urban school A had a mean score of $14.78 ; S D=1.10$ in internal locus of control compared to the mean of $13.57 ; S D=2.44$ in rural school A. We further examined differences in test scores in math, English and science across gender and locality using MANOVA to see if they were significantly different from each other based on the internal-external locus of control scores. As shown in Table 3, male students scored significantly higher in math $(M=57.41 ; S D=18.45)$ and science $(M=64.80 ; S D=18.98)$ compared to female students $(M=48.12 ; S D=19.13)$ and $55.52 ; S D=19.29$ respectively. 
In addition to the means and standard deviations in Table 3, a MANOVA was run to examine if the differences in internal-external locus of control and gender were statistically significant. As shown in Table 4, the mean scores of females were not significantly different from the mean scores of males $F(2,257)=.795, p=.452$; Wilk's $\Lambda=.994, \eta^{2}=.006$. The MANOVA results in Table 4 also shows that while the mean differences in in external locus of control were not significant, mean differences for internal locus of control were significantly different between the two localities $F(6,532)=2.312, \mathrm{p}$ $<.05$; Wilk's $\Lambda=.950, \eta^{2}=.025$. Table 4 also shows that the mean scores for internal locus of control were significantly different between urban school A and urban school B $(\mathrm{p}<.05)$. However, there were no significant differences in internal locus of control scores between the two urban schools and either of the two rural schools. We also wanted to know if students' parental educational level had any influence on their internal-external locus of control beliefs. As shown in Table 4, neither father's nor mother's educational level had any significant influence in students' internal-external locus of control beliefs.

Table 4. MANOVA Results for the Relationship between School Location and I-E Locus of Control

\begin{tabular}{lcccccc}
\hline Effect & Wilks' Lambda & $\mathrm{F}$ & Hypothesis df & Error df & $P$ & $\eta^{2}$ \\
\hline Location of school & .950 & 2.312 & 6.000 & 532.000 & .033 & .025 \\
Gender & .994 & .795 & 2.000 & 257.000 & .452 & .006 \\
Father's level of education & .988 & 1.529 & 2.000 & 257.000 & .219 & .012 \\
Mother's level of education & .998 & .390 & 2.000 & 257.000 & .677 & .003 \\
\hline
\end{tabular}

With regards to academic achievement, MANOVA analysis in Table 5 shows that the test scores between urban and rural schools were significantly different. For example, the math mean scores for students in urban school A were significantly different from the math mean scores of students in urban school B ( $\mathrm{p}<.01)$ and also different from the math scores of students in rural school B (p < .oo1). Similarly, the mean math scores for students in urban school B were significantly different from mean scores of students in both rural schools A and B $(p<.01)$. Similarly, the mean scores in English and science for both urban schools were significantly higher than those in the two rural schools $F(9$, $598.85)=6.44, p<$.oo1; Wilk's $\Delta=.799$, partial $\eta^{2}=.072$. With regards to gender differences in test scores, the mean scores for females and males were significantly different in math: females, $M=48.12$, $S D=19.13$; males, $M=57.41, S D=18.45)$ and science: females; $(M=55.52 ; S D=19.29$; males: $M=64.80$; $S D=18.98)$ but no significant difference was found in the English language. As shown in the MANOVA analysis in Table 5 , these differences were statistically significant, $F(3,247)=13.95$, $\mathrm{p}<.001$; Wilk's $\Delta=.855$, partial $\eta^{2}=.145$. However, students' parental educational level did not have any significant effects on students' assessment scores as shown in Table 5.

Table 5. MANOVA Results for the Relationship between Gender, Location, and Parental Education, and Achievement Scores

\begin{tabular}{|c|c|c|c|c|c|c|}
\hline Effect & Wilks' Lambda & $\mathrm{F}$ & Hypothesis df & Error df & $P$ & $\eta^{2}$ \\
\hline Location of school & .799 & 6.438 & 9.000 & 598.850 & .000 & .072 \\
\hline Gender & .855 & 13.946 & 3.000 & 247.000 & .000 & .145 \\
\hline Father's level of education & .960 & .587 & 15.000 & 585.640 & .886 & .014 \\
\hline Mother's level of education & .919 & 1.206 & 15.000 & 585.640 & .262 & .028 \\
\hline Father X Mother level of education & .809 & .913 & 51.000 & 631.964 & 647 & .068 \\
\hline
\end{tabular}

\section{Discussion}

The purpose of this study was to examine academic outcomes of high school students in the Northern Region of Ghana in relation to internal and external locus of control beliefs. Another 
impetus was to examine if locus of control beliefs as well as academic outcomes vary by gender and locality; that is, urban versus rural high school students. With regards to the first question, we asked that given the cultural value of interdependence, will more students report higher scores on external controls than internal locus of control? The results provided support in the affirmative; out of a possible score of 20 , the mean score for the total sample was 15.94. Consistent with previous studies, this suggests passivity and a "why bother" attitude coupled with a belief in the notion of a "good day" and pure luck (Finch et al., 1981; Kendall et al, 1978; Nowicki, 1976). According to Rotter (1966), external locus of control orientation is characterized by a perception that life events depend on luck, chance or powerful others. Rotter further observed that individuals with external locus of control beliefs perceive events in their life as contingent on fate or under the control of powerful others and not through their own actions. Given that Ghanaians in general tend to live communally and hold collectivistic values to a high esteem, the results of higher external locus of control beliefs is not surprising but should not be interpreted literally. Similar to Kishor (1983) who studied differences in academic outcomes between native Fijians and Fiji-Indians, he discovered that native Fijians who, because of their cultural practices of communal living and collective orientations, they tended to seek group approval in their daily activities. Individual actions also require the approval of people in a higher social rank in the commune. Kishor (1983) insinuated that such experiences were likely to instill among Fijians a belief that rewards are controlled by powerful others, which will intend result in the development of external locus of control.

Unlike many Western countries where the unemployment rate is low, rates of unemployment and underemployment are very high in Ghana. This is further compounded by high levels of corruption coupled with ethnic favoritism. Given this situation, even highly qualified individuals are not guaranteed employment and getting a good job may require personal connections to powerful others (such as corrupt politicians), a type of external locus of control Levenson (1974) attributed to powerful others and life chances (e.g., fate or back luck).

With regards to question two, the study examined the relationship between internal locus of control and test scores in math, English, and science. Contrary to our expections, no significant relationship was found between internal locus of control and all the three test scores. This was sharply in contrast with previous studies that found a positive relationship between internal locus of control and academic outcomes (e.g., Das \& Pattanaik, 2013; Dubey \& Nayyar, 2016; Findley \& Cooper, 1983; Ndom et al., 2018; Nongtu \& Bhutia, 2017). We further examined the relationship between external locus of control and test scores but no relationship was found. In fact, significant inverse relationships were found between external locus of control and test scores in math and English language but not with science suggesting that students who scored higher on external locus of control were more likely to have lower achievement scores in these subjects. These findings are inconsistent with previous research that showed a positive relationship between locus of control and test scores and academic achievement in general. For example, Dubey and Nayyar (2016) investigated the role of locus of control in academic achievement of students in science in secondary school in India and reported that students with internal locus of control performed better than those with external locus of control. However, the inverse relationship between test scores and external locus of control was consistent with existing research. For example, Findley and Cooper (1983), Nongtu and Bhutia (2017), as well as Klein and Wasserstein (1999) found that while high internal locus of control scores enable people to believe in their ability and control over their environment and effectively accomplish self-appointed objectives and tasks, students with high external control scores had lower academic performance and blame others or external forces for their performance. It is unclear why internal locus of control does not seem to motivate academic achievement in our study sample. However, the high external locus of control reported earlier may contribute to learned helplessness when students feel that their effort does not matter.

Furthermore, the study examined gender differences in internal-external locus of control and test scores in math, English, and science. No significant differences were found between gender and internal-external locus of control scores although females scored relatively higher than males in both 
internal and external locus of control beliefs. This was not surprising since existing research findings on gender differences in internal-external locus of control beliefs are mixed. For example, Abid, Kanwal, Nasir, Igbal, and Ul-Huda (2016), Strickland and Haley (1980), and Sarrasin, Mayor, and Faniko (2014) reported higher external locus of control beliefs in female students than their male counterparts. However, other studies such as Khir et al. (2015), Findley and Cooper (1983), Nongtu and Bhutia (2017) reported no significant differences in locus of control beliefs between females and males. Given the gendered nature of African societies and Ghana's in particular and gender discrimination in favor of males generally, the high external scores were not surprising but the higher internal scores need further exploration as females may have recognized their marginalized statuses and adapt accordingly to attain personal independence.

The final question examined the relationship between locus of control, location of school (urban vs. rural), and test scores. Consistent with our expectations, students in rural schools scored significantly higher in external locus of control beliefs than their urban counterparts. With regards to test scores, students in urban schools significantly outperformed their rural counterparts in all subjects. There were also significant gender differences in test scores in math and science with male students performing significantly better than their female counterparts. We also wanted to know whether the parental educational level of students had any influence on students' locus of control beliefs and test scores. However, no significant differences were found among parental education, locus of control beliefs, and test scores. These findings are consistent with past research documenting locality differences in locus of control beliefs and academic achievement (e.g., Khir et al., 2015; Nongtu \& Bhutia, 2017), who, in their study of the relationship between locus of control and academic achievement in India and Malaysia respectively reported higher internal locus of control beliefs among their urban sample compared to their rural counterparts. The authors suggested that academic achievement of the college students with higher internal locus of control believe that their success or otherwise depends on their own effort. We had anticipated that given the communal and interdependent nature of social relationships in Africa, and rural areas in particular, there is an inclination to defer decision-making to adults and people in authority. For that reason, it was not surprising that student in rural schools scored higher on external controls. However, it must be emphasized that the relationship between internal locus of control and test scores may be more nuanced and could be confounded by many factors such as teacher qualifications, access to school supplies, distance from home and means of transportation, just to name a few.

\section{Conclusion and Recommendations for Future Research and Policy}

This study investigated the relationship between locus of control and academic outcomes of high school students in Ghana. While the study found no significant gender and locality differences in locus of control beliefs, a negative relationship was found between external locus of control beliefs and academic outcomes. This suggests that students who believe their effort is useless and that their destiny is controlled by powerful others tend to have lower achievement scores. While this may be the result of the communal and interdependent values of the local culture, it also underscores the need for reforms both at the educational and national level to reduce corruption and engender confidence in young people in their ability to be successful without 'powerful others.' The findings also reaffirmed significant gender gaps in achievement scores in science and math as well as between rural and urban students, and thus suggest that despite recent improvements in enrollment, more work is needed to close the achievement gap between genders and localities. Resource disadvantage, both human and material, remains the bane of poor academic achievement in rural areas and governments need to double their efforts to improve infrastructure and attract more qualified teachers to rural and marginalized schools.

Finally, this study has several limitations that should be taken into consideration when interpreting the results. First, the sample was purposively and conveniently selected and does not represent the views of all high school students in the region or Ghana for that matter. Second, locus 
of control and students' achievement scores were obtained through self-reports which are subject to personal bias. It is also possible that other confounding factors such as socioeconomic status, religious and spiritual beliefs, the political climate (pervasive corruption by public officials), as well as level of community connections, could influence students' beliefs about their ability or lack of power to change their destiny. Future research may address these limitations by selecting larger, more representative samples through random selection. Another suggestion for future research is to use standardized test scores either recorded by the teachers or the West African Examinations Council that is more objective and reliable.

\section{References}

Abdallah, H., Fuseini, M. N., Abudu, A. M., \& Nuhu, Y. (2014). Dilemma of basic school pupils in Northern Ghana with respect to their learning context. Education Research International, 1-13.

Abid, M. A., Kanwal, S., Nasir, M. A. T., Iqbal, S., \& Huda, N. (2016). The effect of locus of control on academic performance of the students at tertiary level. Internal Review of Management and Business Research, 5(3), 860-869.

Abukari, Z. (2018). "Not giving up": Ghanaian students' perspectives on resilience, risk, and academic achievement. Sage Open, 1-13. doi: 10.1177/2158244018820378

Abukari, Z. (2007). Dimensions of youth unemployment in Ghana: A public policy perspective. Journal of Social Development in Africa, 22(2), 83-105.

Abukari, Z., \& Laser, J. A. (2013). Gender differences in academic outcomes among Ghanaian youth: The role of protective and risk factors. Journal of Community Psychology, 41(1), 117-138, doi: 10.1002/jcop.21518

Amponsah, K. D., Ametefe, J., \& Mensah, F. (2012). Factors affecting female students in their performance in science in selected colleges of education in Ghana. Global Research Journal on Mathematics and Science Education, 1, 1-23.

Bening, R. B. (1990). A history of education in Northern Ghana (1907-1976). Accra: Ghana Universities Press.

Chandler, T. A., \& Dugovics, D. A. (1977). A sex differences in research on locus of control. Psychological Reports, $41,47-53$.

Chingtham, T. \& Guite, T. (2017). Parental attitude toward girls' education. Journal of Research and Method of Education, 7(4), 1-6.

Choi, Y. (2007). Academic achievement and problem behaviors among Asian Pacific Islander American adolescents. Journal of Youth and Adolescence, 36, 403-415.

Choudhury, S. A., \& Borooah, I. (2017). Locus of control and academic achievement of undergraduate college students of Guwahati City. International Journal of Humanities and Social Science Invention, 6(4), 66-70. Retrieved from www.ijhssi.org

Chowa, G. A. N., Masa, R. D., Ramos, Y., \& Ansong, D. (2015). How do student and school characteristics influence youth academic performance in Ghana? A hierarchical linear modeling of Ghana YouthSave baseline data. International Journal of Educational Development, 45, 129-140.

Cooke, E., Hague, S., \& McKay, A. (2016). The Ghana Poverty and Inequality Report: Using the $6^{\text {th }}$ Ghana Living Standards Survey. Accra, Ghana: UNICEF.

Das, P. P. \& Pattanaik, P. (2013). Self-esteem, locus of control, and academic achievement among adolescents. International Journal of Scientific Research in Recent Sciences, 1(1), 1-5

Dubey, A., \& Nayyar, S. (2016). Role of locus of control in academic achievement of science students. International Journal of Education and Management, 6(4), 416-419.

Dunne, M., Leach, F., Chilisa, B., Maundeni, T., Tabulawa, R., Kutor, N. . . Asamoah, A. (2005). Gendered school experiences: The impact on retention and achievement in Botswana and Ghana. Educational Papers. London, UK: Department for International Development.

Fentiman, A., Hall, A., \& Bundy, D. (2001). Health and cultural factors associated with enrollment in basic education: A study in rural Ghana. Social Science \& Medicine, 52, 429-439.

Finch, A. J., Spirito, A., Kendall, P., \& Mikulka, P. (1981). Multidimensionality of the NowickiStrickland Locus of Control Scale for Adults. Journal of Personality Assessment, 45(2), 151-154.

Findley, M. J. \& Cooper, H. M. (1983). Locus of control and academic achievement: A literature review. Journal of Personality and Social Psychology, 44(2), 419-427.

Fobih, D. K. (1987). Social-psychological factors associated with school dropout in the Eastern Region of Ghana. Journal of Negro Education, 56(2), 229-239.

Garmezy, N., Masten, A. S., \& Tellegen, A. (1984). The study of stress and competence in children: A building block for developmental psychopathology. Child Development, 55, 97-111. 
Ghana Statistical Service. (2014). Ghana living standards survey: Report of the 6th round. Accra, Ghana: Author.

Kendall, P. C., Finch, A. J. Jr., Little, V. L., Chirico, B. M., \& Ollendick, T. H. (1978). Variations in a construct: Quantitative and qualitative differences in children's locus of control. Journal of Consulting and Clinical Psychology, 46(3), 590-592.

Khir, A. M., Redzuan, M. Hamsan, H. H., \& Shahrinmin, E. (2015) (December). Locus of control and academic achievement among Orang Asli students in Malaysia. $2^{\text {nd }}$ International Conference on Language, Education, Humanities, and Innovation, Kuala Lumpur, Malaysia

Kishor, N. (1983). Locus of control and academic achievement: Ethnic discrepancies among Fijians. Journal of Cross-Cultural Psychology, 14(3), 297-308.

Levenson, H. (1974). Activism and powerful others: Distinctions within the concept of Internal external control. Journal of Personality Assessment, 38(4), 377-383. doi:10.108o/oo223891.1974.10119988

Levenson, H. (1981). Differentiating among internality, powerful others, and chance. In H. M. Lefcourt (Ed.), Research with the locus of control construct (Vol. 1, pp. 15-63). New York: Academic Press.

McWilliam, H. O. A., \& Kwamena-Poh, M. A. (1975). The development of education in Ghana. London; Longman.

Ndom, R. J. E. (2011). Workshop on alternative research paradigm and indigenous knowledge promotion. Department of Psychology, Covenant University, Ota, Ogun State, Nigeria. 14th - 17th February, 2011.

Ndom, R. J. E., Elegbeleye, A. O., \& Sunmonu, F. O. (2008). The role of locus of control and feedback on performance of primary school students. Ife PsychologIA, 16(1), pp. 173-186

Nongtdu, S., \& Bhutia, Y. (2017). Locus of control in relation to academic achievement of college students in Meghalaya. $4^{\text {th }}$ International Conference on Multidisciplinary Research and Practice.

Nowicki, S. (1976). Factor structure of locus of control in children. The Journal of Genetic Psychology, 129, 13-17.

Nowicki, S., \& Duke, M. P. (1974). A locus of control scale for college as well as non-college adults. Journal of Personality Assessment, 38, 136-137.

Nowicki, S., \& Strickland, B. R. (1973). A locus of control scale for children. Journal of Counseling and Clinical Psychology, 40(1), 148-154.

Nunn, G. D., Montgomery., D., \& Nunn, S. J. (1986) Criterion-related validity of the Nowicki-Strickland Locus of Control Scale with academic achievement. Psychology: AQuarterly Journal of Human Behavior, 23, 9- 11.

Rinn, A. N. \& Boazman, J. (2014). Locus of control, academic self-concept, and academic dishonesty among high ability college students. Journal of the Scholarship of Teaching and Learning, 14(4), 88-114. doi: 10.14434/josotl.v14i14.12770

Rotter, J. B. (1966). Generalized expectancies for internal versus external control reinforcement. Psychological Monographs: General and Applied, 8o(1), 1-28.

Rumberger, R. W. (2001, January). Why students drop out of school and what can be done. Paper presented at the conference, "Dropouts in America: How severe is the problem? What do we know about intervention and prevention?" Harvard University.

Saaka, Y. (2001). (Ed.). Regionalism and public policy in Northern Ghana. New York: Peter Lang.

Sarrasin, O., Mayor, E., \& Faniko, K. (2014). Gender traits and cognitive appraisal in young adults: The mediating role of locus of control. Sex Roles, 70, 122-133. doi: 0.1007/s11199-013-0336-6

Schoon, I. (2006). Risk and resilience: Adaptations in challenging times. Cambridge, UK: Cambridge University Press.

Shepherd, S., Owen, D., Fitch, T. J., \& Marshall, J. (2006). Locus of control and academic achievement in high school students. Psychology Reports, 98, 318-322. doi: 10.2466/PRO.98.2.31.322

Shewchuk, R. M., Foelker, G. A. Jr., Camp, C. J., \& Blanchard-Fields, F. (1992). Factorial invariance issues in the study of adult personality: An example using Levenson's locus of control scale. Experimental Aging Research, $18,15-24$.

Skaalvik., M., \& Skaalvik, S. (2004). Self-concept and self-efficacy: A test of the internal/external frame of reference model and predictions of subsequent motivation and achievement. Psychological Reports, 95, 187-202.

Strickland, B. R., \& Haley, W. E. (1980). Sex differences on the Rotter I-E Scale. Journal of Personality and Social Psychology, 39, 930-939.

Tansel, A. (1997). Schooling attainment, parental education, and gender in Cote d'Ivoire and Ghana. Economic Development and Cultural Change, 45(4), 825-856

Werner, E. E., \& Smith, R. S. (1992). Overcoming the odds: High risk children from birth to adulthood. Ithaca, NY: Cornell University Press.

White, H. (2004). Books, buildings and learning outcomes: An impact evaluation of World Bank support to basic education in Ghana. Washington, DC: World Bank. 